\title{
Anything New Under the Sun? Legal Clarifications as a Polish New Tool for Interpreting Business Law
}

\author{
Anna Piszcz ${ }^{1}$ (D) \\ Published online: 29 January 2020 \\ (C) The Author(s) 2020
}

\begin{abstract}
The aim of this article is to critically reflect on the Polish transformation taking place in the interpretation of business law in the form of legal clarifications that can be qualified as a soft law guidance. The article attempts to address the following questions: does the new Polish legal framework offer really novel approaches to the interpretation of business law and/or its tools? What are the peculiarities that characterize the new instrument for the interpretation of business law in the form of legal clarifications? What are the pros and cons of legal clarifications? What is the potential practical importance of the introduced interpretation tool, in particular in the context of certain previously existing tools for the interpretation of legal texts? To this end, first, the article sheds light into types of the interpretation of legal texts as well as soft law guidance. Second, it analyses the distinctive features of legal clarifications. Third, it contains the concise comparison of legal clarifications to certain previously existing instruments. In the last part before the conclusion, the topic required an attempt at an assessment. The point of the analysis in this article was both descriptive and normative.
\end{abstract}

Keywords Law $\cdot$ Business $\cdot$ Economic activity $\cdot$ Interpretation $\cdot$ Soft law $\cdot$ Administration $\cdot$ Legal clarifications

\section{Introduction}

It may generally be assumed that predictable interpretation and application of law enhance legal certainty. The research presented so far has endorsed the importance of legal certainty, notably the need for "calculability of economic action" [4, p. 9; 21, p. 117].

Yet, Poland has not become renowned for a very effective regulatory environment for doing business, which is reflected in "Doing Business" rankings, where

Anna Piszcz

piszcz@uwb.edu.pl

1 Faculty of Law, University of Białystok, Białystok, Poland 
in 2019 it claims 33rd position globally [23, p. 5]. This certainly has an impact on the choice of policy and legal reforms launched by the Poland's successive governments. Morawiecki's government (2017-2019) has continued the implementation of the package of "100 changes for enterprises" and the so-called "Constitution for Business".

With its focus on improving legal certainty as one of the four key pillars in the Constitution for Business [14, pp. 8-9], the government provided the Parliament with the Entrepreneurs' Law Bill including, among others, provisions on legal clarifications [Pol. objaśnienia prawne]. This component of soft law instruments was considered by the drafters as a novel tool for interpreting laws regarding economic activity.

The legislature chose to introduce the legal framework for the legal clarifications into the Act of 6 March 2018-Entrepreneurs' Law ${ }^{1}$ (its Article 33), in effect from 30 April 2018. It is situated in the chapter on handling matters related to economic activity. What does this concept mean? Briefly, it is an "explanation" (interpretation) of legal provisions that govern undertaking, conducting and terminating economic activity with regard to the practical application of those provisions. It is intended to clarify issues of business law. This interpretation tool is dedicated to competent ministers and some other authorities.

The aim of this article is to critically reflect on this transformation taking place in a Polish interpretation in the form of soft law guidance. From the research aim the following questions emerge as being essential to achieving the research aim: does the new Polish legal framework offer really novel approaches to the interpretation of business law and/or its tools? What are the peculiarities that characterize the new instrument for the interpretation of business law in the form of legal clarifications? What are the pros and cons of legal clarifications? What is the potential practical importance of the introduced interpretation tool, in particular in the context of certain previously existing tools for the interpretation of legal texts? The point of the analysis is both descriptive and normative.

\section{Interpretation of Legal Texts}

By studying the works of legal theorists, we can see that they explain the complex interpretation processes related to legal texts using various concepts of interpretation and various underlying assumptions, even though they describe very similar catalogues of directives (rules) of the interpretation of legal texts. An in-depth analysis of all of the facets of the interpretation of legal texts is beyond the scope of this article. However, for the purposes of this article, it is necessary to dedicate some space to types of the interpretation of legal texts.

Theorists distinguish between various types of the interpretation of legal texts depending upon, inter alia, who interprets. These types can be classified as either unofficial interpretation or official interpretation.

${ }^{1}$ Consolidated text Journal of Laws 2019 item 1292, as amended. 
First, unofficial interpretation can take the form of doctrinal (scientific) interpretation. It is carried out by legal scholars, either individual scholars or research institutions, and rests upon scientific operations [18, p. 19; 24, p. 21; 12, p. 12]. Second, unofficial interpretation involves interpreting the content of a legal text by practitioners-experts in the fields and lawyers in the function of legal advisers to various entities, e.g. companies or other organisations or persons [8, part 1.VII.B]. Another category of unofficial interpretation is ordinary interpretation performed by non-lawyers, that is ordinary people. For them, as postulated, their legal rights and obligations should possibly be understandable without consulting lawyers and without going to court [8, part 1.VII.B]. This category of interpreters of legal texts is considered to include also lay judges [15, p. 17].

As for official interpretation, this category includes, first, legal interpretation. It is meant to involve authentic interpretation (the interpretation of a rule by lawmaker) and usual (customary) interpretation (the interpretation of a rule through custom) $[18$, p. $19 ; 11$, p. 130]. However, it should be noted that the term "legal interpretation" has also other meanings and in the widest sense refers to any ascription of a normative meaning to a norm-formulation [1, p. 405]. Authentic interpretation assumes the form of legislation; it has binding force and general character (the character of the creation of a general norm) [10, p. 354]. Usual interpretation follows the rules determined by custom [11, p. 130].

Another type of official interpretation is operative interpretation performed by the law-applying decision-maker, including courts (judicial operative interpretation) and authorities empowered to decide on issues concerning the application of law [24, p. 21; 12, p. 12]. It is performed in the course of application of law. Operative interpretation differs from doctrinal interpretation. The latter is elaborated by the scientific tradition and its standards. It depends also on individual features of the interpreter and has to do with normative constructs and the presupposed properties of the legal system as contexts, whereas the former forms a part of the style of the legal decision. It has to do with, first of all, a different kind of context, namely facts [24, p. 22; 5, p. 333]. It might be that the interpreter performing doctrinal interpretation has her mind set on an unspecified number of cases of a similar kind (establishes the meaning of the interpreted legal text in general) or a concrete situation of application of law as it is in the case of operative interpretation [1, p. 411]. But, as a rule, it is operative interpretation that is case-centred, context-dependent and, as a result, involving a pragmatic component. It must lead to the conclusive determination of the meaning of the interpreted legal text and, consequently, the determination of its legal effects, whereas in the case of doctrinal interpretation, the interpreter is not obliged to determine them conclusively. The final choice between the possible interpretation alternatives determined generally can be left to the law-applying decision-makers [25, p. $91 ; 12$, p. 13]. However, even in the case of doctrinal interpretation, the need to rely upon directives of interpretation and the construct of the rational law-maker is not obviated [5, pp. 344, 354].

Official interpretation also includes interpretation performed by the law-applying decision-maker being granted the competence to interpret legislation generally. Typically, it assumes the form of guidelines, recommendations, communications, 
notices, circulars or other instruments (generically referred to as soft law), as authorities can get quite creative with the terminologies employed.

\section{Soft law Guidance}

Three distinct elements of typical soft law are recognized: their lack of binding force and direct legal effects, the development of rules of conduct, and their practical effect [20, p. 112]. Soft law can be adopted in any policy field and, in recent years, it has been on the rise, becoming more frequent than before. It has played an increasingly important role in regulation of economic activity and a range of soft law in these policy areas (first and foremost in antitrust) is growing year by year, both at the national as well as EU law levels. The issue of soft law is discussed from the perspectives of, inter alia, its origins, contexts, contents, purposes, functions and formats.

A wide array of soft law instruments can be classified on the basis of, among others, their functions and objectives. Senden, who has created what is perhaps the most commonly cited classification of the EU soft law (but useful also in the case of national soft law), has referred to three categories of soft law instruments. These are: (1) preparatory and informative instruments, (2) formal and non-formal steering instruments, (3) decisional and interpretative instruments [20, p. 118; 16, pp. 25-26]. ${ }^{2}$ The latter are of greatest significance in view of the topic of this article. They aim at providing guidance as to the interpretation of existing law (whereas decisional soft law instruments aim at furnishing decisional rules in areas where the authority is entrusted with the power to make decisions in individual cases; thereby, the authority announces how it intends to make use, in certain situations, of powers it enjoys in its competence to make decisions in individual cases). They can equally be pre-legislative or post-legislative, as they can be adopted at all possible stages of the decision-making process, whether that is early, upstream consultation of the stakeholders or downstream implementation of legislative acts. Therefore, soft law instruments (in particular recommendations) can be classified as (1) preceding legislation (having a pre-law function), (2) replacing legislation (having a para-law function), (3) complementing legislation (having a post-law function) [2, pp. 85, 97]. Interpretative soft law instruments give meaning to, among others, indeterminate legal notions contained in hard law (binding legislation). That is in particular the case for post-legislative instruments that are adopted in order to flesh out the legal notions set out in legislation. However, pre-legislative instruments may also fulfil the same function. In this way, both types of instruments can complement binding legislation. ${ }^{3}$

\footnotetext{
${ }^{2}$ At the same time, it is important to remember that in practice also soft law instruments that have a hybrid nature are successfully created and implemented.

3 As for EU recommendations, see opinion of Advocate General Bobek delivered on 12 December 2017, Case C-16/16 P, Kingdom of Belgium v European Commission, ECLI:EU:C:2017:959.
} 
Interpretative soft law instruments can be discussed as regulatory tools from the perspective of their effect on interpreting binding legislation. In this context, the notion of "regulation by publication" is used [22, pp. 199-201]. They do not easily fit within the "black and white" binary distinction between binding and non-binding instruments (they are not binding in the traditional sense). This raises the question about taking soft law guidance into consideration by courts and authorities, its practical consequences or indirect legal effects as well as its implications for the powers endowed upon the authoring side and its quasi-legislative role. However, the practices of the authors of the soft law instruments and the reference to soft law guidance by the courts can be capable of transforming soft law provisions into hard law provisions (codifying, juridifying).

\section{Characteristics of Polish Legal Clarifications}

The Polish Entrepreneurs' Law (Article 33(1)) confers the power to adopt and publish legal clarifications on: (1) "competent ministers", and (2) "authorities" that are granted by separate legislation a competence to draft legal acts and submit them to the Council of Ministers. ${ }^{4}$ They are authorized to adopt legal clarifications within the scope of their competences. This power serves to fulfil their broader statutory duty to strive to ensure that the application of legal provisions in the field of economic activity is uniform. Therefore, if the application of those provisions is considered uniform, there is no greater or lesser degree of doubt tied into their application and they do not appear to cause the divergence of the authorities' decisional practice, the adoption of legal clarifications should not be expected from competent authorities entrusted with a mission to strive for the uniform application of legal provisions.

The scope ratione personae of the power in question includes only authorities that adopt and/or apply legal provisions in the field of economic activity, ${ }^{5}$ first and foremost the Minister of Entrepreneurship and Technology. It is also worth emphasising that the Entrepreneurs' Law (Article 7(1)(4)) contains the broad definition of "authority", which is not controversial in and of itself. Rightly, the definition of "authority" includes public administration authorities, other public authorities, excluding courts, as well as professional self-government bodies, competent in matters of entering into, carrying on and/or ending economic activity.

However, the wording used in Article 33(1) to describe authorities other than ministers differs from the language of separate legislation itself that usually speaks of a competence to draft legal acts and, rarely, a competence to submit them to the Council of Ministers. Because of that, the obvious question arises: Does it significantly narrow the scope ratione personae of the power to adopt legal clarifications? In order to answer this question in negative, one could suggest here an argumentum

\footnotetext{
${ }^{4}$ While the latter, itself, does not have the power to adopt legal clarifications.

5 Therefore, it may appear controversial that on 20th of February 2019 the Commissioner for Patients' Rights adopted legal clarifications on recording, storing and sharing medical information.
} 
a minori ad maius: a competence to draft legal acts should be understood as involving a competence (even though not expressly stated) to submit them to the Council of Ministers as a decision-maker having the right of legislative initiative. A competence to draft legal acts for the purpose of ending up in the "sock drawer" would not make too much sense. Nevertheless, the language of delegating provisions should certainly be more coherent than it is now [17, p. 15].

In addition, it is noteworthy that the Entrepreneurs' Law remains unclear whether the competent authority is in power to interpret only those legal provisions that it applies itself (for instance, Polish competition authority that has nine regional offices), or, to the contrary, it can interpret also other legal provisions applied by subordinate authorities (for example, whether Minister of Finance is in power to interpret legal provisions applied by the National Revenue Administration authorities, subject to specific provisions of the Tax Code). From the perspective of the uniform application of legal provisions, a more restrictive view could be harmful for the entire system. However, such ambiguities should not appear in delegating provisions.

The authors of legal clarifications listed in Article 33(1) of the Entrepreneurs' Law act: (1) on their own initiative (ex officio) or (2) on the application of the Ombudsman for Small and Medium-sized Entrepreneurs. The Act of 6 March 2018 on the Ombudsman for Small and Medium-sized Entrepreneurs ${ }^{6}$ (hereinafter, the SME Ombudsman) provides for the conditions for applying for legal clarifications of legal provisions (Article 9(1)(2)). The SME Ombudsman can apply for their adoption by a competent authority if at least one of stipulated criteria is satisfied, that is legal provisions in question raise doubts in practice, or their application has resulted in conflicting decisions from a competent public administration authority. The SME Ombudsman files the application on her/his own initiative or at the request of an entrepreneur or an entrepreneurial organization. Unsurprisingly, such a request is not binding on the SME Ombudsman. The first-ever SME Ombudsman appointed on 22nd of June 2018, so far, ${ }^{7}$ has applied 15 times to ministers for the adoption of legal clarifications.

Legal clarifications are defined in Article 33(1) of the Entrepreneurs' Law as explanations of provisions that govern entering into, carrying on and/or ending economic activity with regard to the practical application of those provisions. On one hand, their scope ratione materiae seems thus far-reaching in so far as the term "provisions" means provisions of international agreements, national statutes and regulations, as well as EU law.

On the other hand, this scope is narrowed down, as they can explain only provisions that govern entering into, carrying on and/or ending economic activity within the meaning of Article 3 of the Entrepreneurs' Law (activity carried on for the purpose of obtaining income, in the person's own name and on a continuing basis). Therefore, this legal basis applies neither to explaining provisions governing petty economic activities that fall outside the statutory scope of economic activity

\footnotetext{
${ }^{6}$ Journal of Laws 2018 item 648.

${ }^{7}$ Before 1st of September 2019.
} 
(Article 5) nor to explaining provisions governing economic activities expressis verbis excluded from the scope of the Entrepreneurs' Law, among others, agricultural production activities (Article 6). The present concept implies that legal clarifications should explain how economic activities (within a limited and narrow statutory meaning) should be entered into, carried on and/or ended in practice so that they are compliant with applicable legal provisions.

For instance, on 23rd of January 2019 the Minister of Digital Affairs issued the first-ever legal clarifications based on the Entrepreneurs' Law that interpret provisions on holding by employers personal data gathered from work-seekers who eventually were not employed. The legal clarifications adopted by the Minister of Health on 12th of April 2019 explain whether certain amended provisions of the Pharmaceutical Law apply to previously obtained (and still valid) permits for running generally accessible pharmacies. On 2nd of July 2019 the Minister of Family, Labour and Social Policy adopted legal clarifications on art. 1 of Regulation (EU) No 1231/2010 of the European Parliament and of the Council. They explain procedures of obtaining an A1 certificate by employers from the Social Security Institution in compliance with the General Court judgment adopted in Balandin case. ${ }^{8}$

This is quite different to certain soft law instruments adopted on the basis of previously existing separate legislation, in particular clarifications adopted by the Polish competition authority with regard to antitrust provisions on, inter alia, the method of setting fines, statement of objections or commitment decisions. The delegating provisions of competition law do not stipulate any conditions under which they can be adopted which faced criticism in the academic literature [3, p. 141]. They cannot be qualified as legal clarifications in the meaning of the Entrepreneurs' Law, as the interpreted provisions do not govern entering into, carrying on and/or ending economic activity. Instead, these provisions stipulate (even though not without blurriness) how a public administration authority should proceed in certain cases of law infringements by entrepreneurs. From this perspective, the Entrepreneurs' Law seems to restrict the definition of legal clarifications too excessively, thereby limiting the practical role of the introduced instrument.

Pursuant to the Entrepreneurs' Law, legal clarifications are to be written taking into account in particular the jurisprudence of courts, the Constitutional Tribunal and the Court of Justice of the European Union (Article 33(1)); this enumeration is not complete, so the question arises whether the author of legal clarifications should also take its own previous jurisprudence into consideration. Article 33(1) seems to indicate that the former is above and takes precedence over the latter. On the other hand, it must be said that, according to Article 14 of the Entrepreneurs' Law, without a justified reason, authorities must not depart from the fixed decisional practice in the same factual and legal status quo.

In practice, in particular more complex situations, for example, where diverging jurisprudence of courts is involved, should be addressed by legal clarifications.

\footnotetext{
8 Judgment of the Court of 24 January 2019, Case C-477/17, Raad van bestuur van de Sociale verzekeringsbank v D. Balandin and Others, ECLI:EU:C:2019:60.
} 
Then, the author cannot only describe the lines of diverging jurisprudence but needs to make a justified choice between the alternative lines of jurisprudence.

The same requirements apply to amendments to legal clarifications (Article 33(2)). The author can amend legal clarifications in the case of recognizing that they have been incorrect, either from the very beginning or, as the case may be, as a result of subsequent changes to jurisprudence (when taking into account in particular the jurisprudence of courts, the Constitutional Tribunal and the Court of Justice of the European Union). However, the author would better be obliged to make amendments in such cases and not only be entitled to do so.

\section{Concise Comparison to Certain Previously Existing Instruments}

Neither soft law nor interpretative instruments are new to Polish public administration. In over a decade interpretative instruments have been on the rise in particular in the field of tax law and soft law instruments - in the field of antitrust. The practice of Polish competition authority in this latter area has been largely inspired and to some extent modelled on the practice of European Commission as an EU competition authority.

However, the use of interpretative instruments in Poland can be traced back to a period before 1989, even though they have been assessed as being of poor overall quality [13, p. 480]. Ministers used to adopt circulars, guidelines and instructions (administrative policy instruments, technical instruments, but also interpretative instruments) addressed to subordinate authorities that were binding on the latter [13, pp. 473-477]. There were also non-binding recommendations and opinions distributed within public administration [9, pp. 88ff]. Specific instruments are general interpretations of tax law adopted by Minister of Finance, aimed at the uniform application of tax law and governed by the Tax Code (Article 14a) which are, however, left outside this article due to their narrow ratione materiae scope.

Poland as an EU member state is marked by a proliferation of various interpretative (including soft law) instruments. ${ }^{9}$ The existing types, as well as non-typified and non-formalized forms of official interpretative instruments, are already well reviewed in the scholarly literature [3, pp. 122-124]. It is shown that they are heterogeneous not only by terminologies, but also by their contents and level of detail, either their own or that of provisions comprising their legal bases.

Newly-regulated legal clarifications are not a means of universally binding interpretation of legal text, such as authentic interpretation, but they have several important legal consequences outlined in the Entrepreneurs' Law (Article 35(1) as applied mutatis mutandis). Legal clarifications are not binding on the entrepreneur, so compliance with them is entirely voluntary. However, if the entrepreneur complies with them, administrative sanctions, financial sanctions and fines cannot be imposed on her/him, not to mention it is also inadmissible to charge her/him with higher public levies compared to those implied by legal clarifications. Any amendment to legal

\footnotetext{
${ }^{9}$ Poland joined the EU on 1st of May 2004.
} 
clarifications cannot affect the situation of entrepreneurs who, before the amendment, complied with the legal clarifications in their previous wording (Article $33(2))$.

With all these benefits in mind, it should be emphasized that such legal effects are produced also by certain previously existing tools for the interpretation of legal texts, be it individual interpretations (Article 34), including revenue rulings governed by the Tax Code, or the so-called fixed interpretative practice of a competent authority or a competent state organizational unit (Article 35(4)). Even if these too are interpretative instruments aimed at increasing legal certainty and transparency, they are different from legal clarifications [17, p. 19].

Individual interpretations that established themselves as a vital means of the interpretation of legal texts are related to specific factual situation. They serve as a means of the interpretation of legal provisions providing for the entrepreneur's obligations relating to the payment of public levies and/or social security contributions and/or health insurance contributions. So, the scope of legal provisions interpreted by way of legal clarifications is much broader. An individual interpretation can be received from a competent authority or a competent state organizational unit on the entrepreneur's application (and it is different from how the adoption of legal clarifications is initiated) subject to an affordable fee of PLN 40. It is around EUR 9, per each factual situation. An individual interpretation is an administrative decision that the applicant has the power to appeal. Individual interpretations are an example of operative interpretation of law and cannot be qualified as soft law instruments. Furthermore, the individual interpretation is binding on the authorities or state organizational units competent for the entrepreneur. It can be amended only as a result of resuming the proceedings; however, the individual interpretation that resulted in irreversible legal effects cannot be amended at all.

A form of the interpretation of legal texts that can be relied on by entrepreneurs from 1st of January 2017 and is different from both individual interpretations and legal clarifications is the so-called fixed interpretative practice of a competent authority or a competent state organizational unit. What does this concept add that is not already present within the former notion? Such fixed practice serves as a means of the interpretation of the same scope of legal provisions as in the case of individual interpretations. It is defined as explanations that prevail in individual interpretations adopted in the case of identical factual situations and the same legal status quo in a given reference period and in the 12 months before its beginning. This type of "self-service" interpretative instrument does not require any application filed by the entrepreneur. It is unofficial interpretation producing legal effects defined by statutory provisions, based on a range of official (more precisely, operative) interpretations. However, it implies that, in order to rely on it, the entrepreneur needs to compile (sometimes) large numbers of individual interpretations, decide which of them (adopted in the same legal status quo) are related to identical factual situations and what line of interpretation prevails in them. There is therefore a significant risk of mistakes being made and for entrepreneurs to be adversely affected through their misguided approach to the fixed interpretative practice. In contrast, legal clarifications are supposed to provide entrepreneurs with clear and unambiguous interpretation of the law in the area of economic activity. 


\section{Attempt at an Assessment}

The Polish government's declaration that the Entrepreneurs' Law is a statute better adapted to the expectations of entrepreneurs and serious development challenges facing the Polish economy may generate much discussion as well as scepticism and even rejection. It is difficult to see many original solutions in the statute that would serve such purposes. In the context of the Polish Constitution, the government has wanted legal clarifications to fulfil the public authorities' duty to provide entrepreneurs with the positive benefits supporting economic activity and be a manifestation of a kind of legal assistance for entrepreneurs. By its very nature it must not cause any harm to them. The provisions on legal clarifications have been intended to develop, detail and safeguard the principles derived from the principle of a democratic state ruled by law contained in Article 2 of the Polish Constitution. Many constitutional principles are not explicitly encompassed by separate constitutional provisions, but they are inferred from the above-mentioned principle [7, pp. 56-57; 19, pp. 34-37]. These are, inter alia, the principle of the protection of trust in the state and its laws as well as the principle of legal certainty. The government's declarations that the Entrepreneurs' Law shall provide the broader statutory guarantees of these principles are only general affirmations that, in themselves, do not have the nature of legal guarantees. However, the opposite view can be held with regard to the concept of legal clarifications that, against this background, seems quite unique and capable of playing an important role in practice, as it fills a gap in the toolbox available regarding the interpretation of business law. They, indeed, may increase the level of stability of the application of law (its uniformity in the territory of Poland), transparency of administrative activities and legal certainty of entrepreneurs, thus increasing the degree of legal awareness and legal culture of entrepreneurs.

In addition to the above, the new concept seems to give a valuable opportunity for a dialogue between market participants and authorities. As business law permanently raises doubts in practice, entrepreneurs will probably address the competent authorities on the need to adopt legal clarifications. To that end, entrepreneurs' representatives may request the SME Ombudsman for her/his applications to the competent authorities or consider direct talks with the authorities. The former may be a far better option, as the SME Ombudsman seems quite active and the number of the applications filed thereby so far (15) is greater than a handful of legal clarifications adopted by the authorities both on the application and ex officio. No matter the chosen approach, it remains to be seen whether the competent authorities will prove ready to provide legal clarifications needed by entrepreneurs (explain the existing legal provisions raising doubts, present their views on them and clarify them) or, quite paradoxically, will avoid to choose and endorse the interpretation. In fact, at least for now, only a modest list of legal clarifications has been published. It can also be speculated that legal clarifications may be an important factor in reducing numbers of applications for individual interpretations. On the other hand, it can be recommended that legal clarifications should be adopted with regard to issues that typically result in numerous entrepreneurs' applications for individual interpretations. 
Legal clarifications as official interpretative soft law instruments should interpret legislation generally, so as not to mix with the scope reserved for individual interpretations. It goes without saying that the duty to observe the principle of equal treatment lays at the very heart of legal clarifications. By their publication, the competent authority imposes a limit on the exercise of its powers and cannot depart from its interpretation. Legal clarifications produce legal effects vis-à-vis their authors by limiting the exercise of their powers.

The delegating provisions do not contain much guidance for the competent authorities to be used in writing their legal clarifications. Neither the form nor the content of legal clarifications are pre-given. Therefore, among them, there are legal clarifications in the form of a letter to the SME Ombudsman applying for their adoption. ${ }^{10}$ Their text is unstructured. Bold and/or underline are used to highlight/emphasise important points. A bad first impression is created by that one of the documents contains typos. ${ }^{11}$ On the other, signed in ink (and not electronically), a stamp of the official has been put upside down. ${ }^{12}$

Although the devil will be often in the detail when it comes to legal clarifications, on the face of it their conclusions should help entrepreneurs to interpret legal provisions raising doubts. The government has embraced the principle that legal clarifications should be written in an understandable, accessible and simple language [14, p. 9], even though it is reiterated neither in the Entrepreneurs' Law nor in the accompanying explanatory memorandum. However, the talk of simple language may be considered wishful thinking if we take into account that, in general, translating legal language and complex legal ideas — for the sake of transparency — into everyday language seems mission impossible. No matter the "disclaimers" of the government, it would be hardly possible (if not impossible) to deliberately draft legal clarifications using non-legal terminology for transparency purposes and, at the same time, provide an interpretation of legal provisions in them.

The language of legal clarifications published so far can, indeed, be seen as very difficult (not simpler than that of the interpreted legal provisions). It is striking that authors of the above-mentioned legal clarifications in the form of a letter to the SME Ombudsman have written them like lawyers write to lawyers. These are not documents aimed to make an average entrepreneur aware of certain variants and to offer a sound interpretation of law. They are rather for their lawyers who can assist them with interpreting interpretations, such as "Insofar as an interpretation according to which the entity that was obliged to comply with the personal requirements provided for in article 99 section 4 u.p.f. [Pharmaceutical Law] at the stage of obtaining the

\footnotetext{
${ }^{10}$ Legal clarifications of 12 April 2019 on whether amended provisions of the Pharmaceutical Law apply to previously obtained permits for running generally accessible pharmacies, adopted by the Minister of Health; legal clarifications of 2 July 2019 on art. 1 of Regulation (EU) No 1231/2010 of the European Parliament and of the Council, adopted by the Minister of Family, Labour and Social Policy.

11 Legal clarifications of 12 April 2019 on whether amended provisions of the Pharmaceutical Law apply to previously obtained permits for running generally accessible pharmacies, adopted by the Minister of Health.

12 Legal clarifications of 2 July 2019 on art. 1 of Regulation (EU) No 1231/2010 of the European Parliament and of the Council, adopted by the Minister of Family, Labour and Social Policy.
} 
permit is obliged to comply with them also after obtaining that permit is rational from the point of view of a teleological interpretation of this provision, the adoption of an analogous requirement with regard to entities which obtained the permit before the introduction of this obligation is unjustified" and "The opposite interpretation would lead to the conclusion that the legislature in fact obliged holders of permits for operating a generally accessible pharmacy to adapt to new personal requirements, specifying neither the deadline for fulfilling this obligation nor consequences of failure to comply with it". 13

Essentially, legal clarifications are quite long (even 23-pages long ${ }^{14}$ ). Some authorities push themselves to a higher level of quality creating useful structures of legal clarifications. For instance, contents of 7-page document clarifying the issue of holding by employers personal data gathered from work-seekers who eventually were not employed ${ }^{15}$ range from the reference to the SME Ombudsman's application, a brief description of what the document is about and its goal, to a part related to work-seekers who have agreed to use their recruitment documents for future recruitments and a part related to work-seekers who have provided their recruitment documents to participate in specific recruitment. The vital accent in these legal clarifications is that they combine the interpretation of legal provisions with three practical examples of their application. They describe what happens and what measures are recommended, for instance:

"Situation 2: A CV is sent to the company by e-mail with information in the message that the work-seeker would like to be included in any future recruitments.

Recommended action: This message should be considered as consent to the processing of personal data by a potential employer for purposes related to the organization of employee recruitment. Additionally (as in the example 1), the information obligation should be fulfilled pursuant to article 13 of the General Data Protection Regulation (GDPR). Under this obligation, you should inform, among others, about the legal basis for data processing, i.e. that it is the aforementioned article 6(1)(a) GDPR. As in the situation described above, given the participation of this person in future recruitments and the fact that this person may not get a job as a result of participation in recruitments, it is worth that the company already at this stage reserved to itself the right to process data for the purposes of possible pursuit of redress-on this occasion pointing out as the basis for this purpose also article 6(1)(f) GDPR (i.e. the legitimate interest of the administrator)."

The competent authorities will need to know generally recognized directives of the interpretation of legal texts and what can be reasonably inferred from the available rules. They should not interpret business law statically, but dynamically, as the meaning of a legal provision can change over time [6, pp. 9ff]. Certainly, the

\footnotetext{
13 Legal clarifications of 12 April 2019 on whether amended provisions of the Pharmaceutical Law apply to previously obtained permits for running generally accessible pharmacies, adopted by the Minister of Health.

14 Legal clarifications of 20 February 2019: Re-cording, storing and sharing medical information-practical issues, adopted by the Commissioner for Patients' Rights.

15 Legal clarifications of 23 January 2019: Holding by employers personal data gathered from workseekers who eventually were not employed, adopted by the Minister of Digital Affairs.
} 
competent authorities must not be the decisive rule-makers for legally relevant questions. They must not go beyond the boundaries set by the interpreted legal provisions, as they currently stand, or interpret them in a way which would reduce their scope or which would contravene the aims of those legal provisions. The competent authorities cannot appoint themselves as alternative legislative bodies and "amend" hard law through soft law instruments. In legal clarifications the authorities can express their view on the interpretation of the relevant concepts, including indeterminate or open legal notions in business law. Legal clarifications should be a reflection of the relevant jurisprudence interpreting the relevant business law provisions. Specifically, in legal clarifications the authorities are limited to expressing their understanding of business law provisions, as interpreted by courts. On issues that have not yet been considered by courts, the authorities may set out how they consider that interpreted legal notions should be construed.

The ultimate judges of all such interpretations of legal provisions remain courts. Legal clarifications cannot be seen as binding on courts. The opposite view would disregard the constitutional principles. If the authority refers to the interpretation provided for in legal clarifications in its decision appealed to the court, the court shall be able to use its discretion whether to assess them (as a soft law measure) in its judgment (and, if so, in what way) or confine itself to the reference to legal provisions interpreted by legal clarifications.

It is fair to say that when regulating legal clarifications, the Polish legislature missed the perfect opportunity. The legislature could have set in some order the legal provisions on interpretative soft law instruments scattered around the legal system (within business law). Instead, the legislature refrained from it, introducing and regulating too narrowly understood legal clarifications in the Entrepreneurs' Law. Moreover, certain important issues were ignored, such as the need to regulate at least some elements of procedures for creating interpretative soft law and mechanisms of its supervision that has already been avowedly postulated in the scholarly literature [3, p. 152].

\section{Conclusion}

It may be that the introduction of the new tool for interpreting business law through adopting formally non-binding legal clarifications marks the beginning of a de facto innovative and quite open approach towards interpretative soft law instruments. Legal clarifications may integrate traditional law making with the flexibility required by the context. It remains to be seen, however, whether reliance on legal clarifications intended to have an important impact on entrepreneurs will gain in popularity. On the other hand, the still modest recourse to legal clarifications by the competent authorities proves the lack of tendency to "fix" an outdated hard law with soft law, without waiting for legislative amendments that are needed. Such a tendency, if it were indeed in play, would be pathological in that the authorities would try to circumvent the constitutional limits of their mandate, thereby contradicting constitutional principles. 
This analysis leads to the conclusion that legal clarifications can be of considerable practical importance. They are aimed at a uniform, coherent and consistent application of hard law. They are supposed to have the effect of providing legal certainty, thus contributing to legal stability. At the same time, they are not a "weak" form of soft law, because they are expressly meant to have legal value. They, if complied with by entrepreneurs, protect their legitimate expectations and protect them from sanctions. Legal clarifications can help entrepreneurs to understand legal provisions as well as what the boundaries of their activities should be in order not to infringe law and what they should expect in case of infringements.

The lack of practical experience with legal clarifications raises questions regarding the role of the system of judicial protection vis-à-vis these interpretative soft law instruments. Of course, it will be very interesting to see legal clarifications relied on by the competent authorities and/or entrepreneurs, challenged before courts, and the courts' views on Article 33 of the Entrepreneurs' Law. It cannot be known now, however, whether they will generate any legal battles before courts.

In spite of the generally positive outcomes shown by the above analyses, it should be noted that the "prototype" model of legal clarifications is not free of limitations, misstatements, difficulties and dangers. They concern, among others, the scope ratione personae of the power to adopt legal clarifications, but also their too narrow scope ratione materiae. Regrettably, the Polish legislature has not taken a holistic and universal approach to regulating interpretative soft law instruments, thereby leaving (within business law) various legal provisions on interpretative soft law instruments scattered around the legal system. There is a need for debate revolving around whether the introduced legal bases are sufficient to achieve envisaged goals or whether, de lege ferenda, something more needs to be done with the regulation of interpretative soft law instruments (within business law).

Several examples of legal clarifications can already be seen in practice. Nonetheless, only time will tell if the competent authorities will continue to adopt legal clarifications, and if so, what will be their quality.

Open Access This article is licensed under a Creative Commons Attribution 4.0 International License, which permits use, sharing, adaptation, distribution and reproduction in any medium or format, as long as you give appropriate credit to the original author(s) and the source, provide a link to the Creative Commons licence, and indicate if changes were made. The images or other third party material in this article are included in the article's Creative Commons licence, unless indicated otherwise in a credit line to the material. If material is not included in the article's Creative Commons licence and your intended use is not permitted by statutory regulation or exceeds the permitted use, you will need to obtain permission directly from the copyright holder. To view a copy of this licence, visit http://creativecommons.org/licen ses/by/4.0/.

\section{References}

1. Aarnio, A., and N. MacCormick. 1992. Legal Reasoning, vol. II. New York: New York University Press.

2. Andone, C., and S. Greco. 2018. Evading the Burden of Proof in European Union Soft Law Instruments: The Case of Commission Recommendations. International Journal for the Semiotics of Law 31(1): 79-99. 
3. Błachucki, M. 2014. Urzędowe wyjaśnienia przepisów prawa wydawane przez organy administracji publicznej. In Źródła prawa administracyjnego a ochrona wolności i praw obywateli, ed. M. Błachucki and T. Górzyńska. Warsaw: Naczelny Sąd Administracyjny.

4. Chowdhury, N. 2014. European Regulation of Medical Devices and Pharmaceuticals. Regulatee Expectations of Legal Certainty. Cham: Springer.

5. Dascal, M. 2003. Interpretation and Understanding. Amsterdam and Philadelphia: John Benjamins.

6. Eskridge Jr., W.N. 1994. Dynamic Statutory Interpretation. Cambridge and London: Harvard University Press.

7. Garlicki, L. 1999. The Principles of the System of Government in the Republic of Poland. In The Principles of Basic Institutions of the System of Government in Poland, ed. P. Sarnecki, A. Szmyt, and Z. Witkowski. Warsaw: Wydawnictwo Sejmowe (Sejm Publishing Office).

8. Greenawalt, K. 2010. Legal Interpretation: Perspectives from Other Disciplines and Private Texts. New York: Oxford University Press.

9. Hoff, W. 1987. Wytyczne w prawie administracyjnym. Warsaw: Państwowe Wydawnictwo Naukowe.

10. Kelsen, H. 2005. Pure Theory of Law. Clark, New Jersey: The Lawbook Exchange.

11. Kevelson, R. 2012. The Law as a System of Signs. New York and London: Plenum Press.

12. Linderfalk, U. 2007. On the Interpretation of Treaties: The Modern International Law as Expressed in the 1969 Vienna Convention on the Law of Treaties. Dordrecht: Springer.

13. Litwin, J. 1965. Drogi ujednolicenia wykładni prawa administracyjnego. Państwo i Prawo 10(236): $472-483$.

14. Ministry of Entrepreneurship and Technology/Ministerstwo Przedsiębiorczości i Technologii. 2018. Konstytucja Biznesu i inne zmiany prawne dla firm (Constitution for Business and other legal amendments for firms). Warsaw: Ministerstwo Przedsiębiorczości i Technologii.

15. Orlov, V. 2016. Introduction to Business Law in Russia. London and New York: Routledge.

16. Peters, A. 2011. Soft Law as a New Mode of Governance. In The Dynamics of Change in EU Governance, ed. U. Diedrichs, W. Reiners, and W. Wessels. Cheltenham and Northampton: Edward Elgar Publishing.

17. Piszcz, A. 2018. Objaśnienia prawne według ustawy z 6.3.2018 r.-Prawo przedsiębiorców. Monitor Prawniczy 13(suppl.): 14-19.

18. Pound, R. 1914. Readings in Roman Law and the Civil Law and Modern Codes as Developments Thereof: An Introduction to Comparative Law, part 1. Cambridge: Harvard University Press.

19. Prokop, K. 2011. Polish Constitutional Law. Białystok: Temida 2.

20. Senden, L. 2004. Soft Law in European Community Law. Oxford and Portland, Oregon: Hart Publishing.

21. Siems, M. 2017. Comparative Legal Certainty: Legal Families and Forms of Measurement. In The Shifting Meaning of Legal Certainty in Comparative and Transnational Law, ed. M. Fenwick, M. Siems, and S. Wrbka. Oxford and Portland, Oregon: Hart Publishing.

22. Snyder, F. 1994. Soft Law and Institutional Practice in the European Community. In The Construction of Europe: Essays in Honour of Emile Noël, ed. S. Martin. Alphen aan den Rijn: Kluwer Law International.

23. World Bank Group. 2019. Doing Business 2019. Washington, DC: The World Bank.

24. Wróblewski, J. 1989. Contemporary Models of the Legal Sciences. Wrocław: Zakład Narodowy im. Ossolińskich.

25. Wróblewski, J., Z. Bańkowski, and N. MacCormick. 2013. The Judicial Application of Law. Dordrecht: Springer.

\section{Legislation and Soft-Law Guidelines}

Act on the Ombudsman for Small and Medium-sized Entrepreneurs of 6 March 2018, Journal of Laws 2018 item 648 (ustawa z 6 marca 2018 r. o Rzeczniku Małych i Średnich Przedsiębiorców, Dz.U. 2018 poz. 648).

Constitution of the Republic of Poland of 2 April 1997, Journal of Laws 1997, No 78, item 483, as amended (Konstytucja Rzeczypospolitej Polskiej z. 2 kwietnia 1997 r., Dz.U. 1997 Nr 78, poz. 483, ze zm.). 
Entrepreneurs' Law - Act of 6 March 2018, consolidated text Journal of Laws 2019 item 1292, as amended (ustawa z 6 marca 2018 r. - Prawo przedsiębiorców, tekst jedn. Dz.U. 2019 poz. 1292, ze $z m$.).

Legal clarifications of 23 January 2019: Holding by employers personal data gathered from work-seekers who eventually were not employed, adopted by the Minister of Digital Affairs (Objaśnienia prawne z 23 stycznia 2019 r. wydane przez. Ministra Cyfryzacji: Dalsze gromadzenie danych osobowych osób ubiegajacych się o zatrudnienie u pracodawcy po zakończeniu rekrutacji).

Legal clarifications of 20 February 2019: Re-cording, storing and sharing medical information - practical issues, adopted by the Commissioner for Patients' Rights (Objaśnienia prawne z 3 października 2019 r. wydane przez Rzecznika Praw Pacjenta: Udostępnianie, prowadzenie i przechowywanie dokumentacji medycznej-zagadnienia praktyczne).

Legal clarifications of 12 April 2019 on whether amended provisions of the Pharmaceutical Law apply to previously obtained permits for running generally accessible pharmacies, adopted by the Minister of Health (Objaśnienia prawne z 12 kwietnia 2019 r. wydane przez. Ministra Zdrowia dotyczace możliwości i zakresu stosowania ustawy z dnia 7 kwietnia 2017 r. o zmianie ustawy - Prawo farmaceutyczne 2017 r.”) w odniesieniu do zezwoleń na prowadzenie aptek ogólnodostępnych wydanych przed wejściem $w$ życie tejże ustawy).

Legal clarifications of 2 July 2019 on art. 1 of Regulation (EU) No 1231/2010 of the European Parliament and of the Council, adopted by the Minister of Family, Labour and Social Policy (Objaśnienia prawne z 2 lipca 2019 r. wydane przez. Ministra Rodziny, Pracy i Polityki Spotecznej dotyczqce art. 1 Rozporzadzenia Parlamentu Europejskiego i Rady (UE) nr 1231/2010).

Pharmaceutical Law - Act of 6 September 2001, consolidated text Journal of Laws 2019 item 499, as amended (ustawa z 6 września 2001 r. - Prawo farmaceutyczne, tekst jedn. Dz.U. 2019 poz. 499, ze $z m$.).

Tax Code - Act of 29 August 1997, consolidated text Journal of Laws 2019 item 900, as amended (ustawa z 29 sierpnia 1997 r. - Ordynacja podatkowa, tekst jedn. Dz.U. 2019 poz. 900, ze zm.).

Publisher's Note Springer Nature remains neutral with regard to jurisdictional claims in published maps and institutional affiliations. 